\title{
Wind Farming Feasibility Assessment in 16 Locations of Nepal
}

\author{
Raju Laudari ${ }^{1}{ }^{*}$, Bal Krishna Sapkota ${ }^{1}$, Kamal Banskota ${ }^{2}$ \\ ${ }^{1}$ Department of Science and Humanities, Pulchowk Campus, Institute of Engineering, Tribhuvan University, Nepal \\ ${ }^{2}$ Department of Economics, School of Arts, Kathmandu University, Nepal \\ Corresponding E-mail: raju.laudariegmail.com
}

\begin{abstract}
:
The paper assesses the feasibility of wind farming at the 16 sites scattered in different ecological regions of Nepal. The wind speed, the hourly and seasonal variation of wind, the wind-rose, the wind turbulence rate, the wind power density, the Weibull probability distribution and the frequency of the wind speed above cut in speed were computed. The average wind speed at all the sites was found to be higher during the dry season from March to May. The wind speed of the modern turbine for power generation at eight sites was found to be above cut-in speed. However, the wind power density was found to be good only at the two sites and fairly good at the six sites. More than $50 \%$ time of a year at these eight sites had over $3.5 \mathrm{~m} / \mathrm{s}$ wind speed. However, the turbulence rate at all the studied sites was found to be above the acceptance range of $25 \%$. Among the study sites, Kagbeni, Thini, Jumla, Ramechhap, Vorleni, Patan west, Hansapur and Baddanda were found to be technically feasible sites for wind energy generation in Nepal.
\end{abstract}

Keywords: Feasibility Assessment, Weibull Distribution, Wind Farming, Wind Rose, Wind Speed

\section{Introduction}

Nepal with the total area of 147,181 square kilometers is located between $26^{\circ} 26^{\prime}$ to $30^{\circ} 26^{\prime}$ north latitudes and between $80^{\circ} 03^{\prime}$ to $88^{\circ} 15^{\prime}$ east longitudes. The elevation of the terrain ranges from $70 \mathrm{~m}$ to $8,848 \mathrm{~m}$ from the sea level. $17 \%$ of the land is flat terrain, $68 \%$ is covered by hills and the remaining $15 \%$ is covered by high mountains. Temperature varies with the variation in the altitudinal range from almost tropical to alpine. So, there is wide diversity in landscape, altitude, topography and temperature in the nation.

One of the barriers of Nepal's economic growth is severe shortage of modern and clean energy supply. Traditional biomass and imported fossil fuels have high dominance in the total energy supply of Nepal. However, the share of biomass energy has decreased from $86.7 \%$ in 2000 to $79.4 \%$ in 2014 whereas the fossil fuel share increased from $11.5 \%$ to $17.2 \%$, and the share of renewable energy including hydropower went up from $1.7 \%$ to $3 \%$. In 2000 , the per capita energy consumption was 14.76 GJ which reached to $18 \mathrm{GJ}$ in 2014/015 [1,2]. Nepal's miserably low per capita energy consumption and reliance on biomass is not a viable means to propel development. The estimated hydropower potential of Nepal is 83,000 MW of which 45,610 MW has been identified as economically feasible [3]. Nepal has high solar radiation; thus, it has good solar energy potential as compared to other parts of the world
[4]. However, endowment of wind resource has not been adequately explored in Nepal.

\section{Literature Review}

Grieser et al. highlighted the importance of small wind turbine for developing countries in the context of rural electrification [5]. In the global context, wind energy began to emerge in the 1970s, partly in response to the oil crisis [6]. The theoretical wind energy supply potential is significantly higher than the global energy demand [7]. However, the major obstacle of wind power is the intermittent nature of wind resources. The Solar and Wind Energy Resource Assessment reports have also pointed out the need of further analysis and research for a complete assessment to identify micro-level potential of the wind resource in Nepal $[8,9]$. Nepal has complex and varied topography within a short span of area. Due to mountainous and difficult topography with canyon and valley, ten-kilometer resolution modeling does not capture the wind data of the required location properly in Nepal [10]. Adequate research has not been carried out about feasibility of wind power generation and its potential contribution in national energy supply in Nepal. This research was conducted in 16 locations of Nepal, scattered in various part of the country, to assess the feasibility of wind energy generation in Nepal. The analysis of wind speed variations, and the wind characteristics like wind rose, Weibull distribution, wind power density and wind turbulence rate are necessary to assess the feasibility of 
wind farming. For evaluation of the wind potential of a site, it is indispensable to know the wind speed distribution. The monthly, yearly and seasonal variation in wind characteristics has to be analyzed [11].

Similarly, the amount of energy available from wind depends on the speed of wind. The speed of wind, on the other hand, is determined by air density, air temperature, air pressure, and altitude. Temperature decreases with height, while pressure increases accordingly. Wind effects are more pronounced at high altitudes. The wind speed decreases with the increase in air density [12]. Similarly, from the atmospheric stability point of view, vertical profile of the wind speed is variable in time, both on daily and seasonal basis [13]. Yearly assessment of almost every wind characteristic parameter, probability distribution, wind power and energy densities and wind direction distribution are carried out in assessing the wind potential [14].

The most common dataset used in the analysis of wind resources is weather station data as it objectively measures the actual wind speed at certain sites [15]. The wind speed measured at a meteorological station is determined mainly by the overall weather systems and the nearby topography [16]. The minimum duration of wind data collection should be one year, but two or more years will produce more reliable results. One year is usually sufficient to determine the diurnal and seasonal variability of the wind. Geographical and temporal variability increases the difficulty in an accurate prediction of wind [17]. The degree of uncertainty depends on the abundance and quality of wind data, the complexity of the terrain and the geographical variability of the wind resource [18].

A detailed wind data assessment show where it is windy and during what time of the day and year winds tend to be strongest. Inaccuracy of $\pm 5 \%$ in wind measurement can lead to approximately $\pm 10 \%$ inaccuracy in annual energy production, which in turn will lead to $\pm 10 \%$ inaccuracy in revenue, and finally this inaccuracy can be the difference between a financially viable and a financially unviable wind project [19].

Garrad has classified mean wind speed into approximately $\operatorname{good}(6.5 \mathrm{~m} / \mathrm{s}), \operatorname{good}(7.5 \mathrm{~m} / \mathrm{s})$, and very $\operatorname{good}(8.5 \mathrm{~m} / \mathrm{s})$ [20]. The stable wind speed of around $3 \mathrm{~m} / \mathrm{s}$ over the year, which is smaller than the typical cut-in speed where turbines start, leads to zero production. On the other hand, a wind speed with high fluctuations around the mean of 3 $\mathrm{m} / \mathrm{s}$ leads to much higher production [13]. In general, wind speeds are grouped into four categories: i) minimum 2 $\mathrm{m} / \mathrm{s}$, which is required to start rotating most small windturbines, ii) $3.5 \mathrm{~m} / \mathrm{s}$, the typical cut-in speed, when a small turbine starts generating power, iii) $10-15 \mathrm{~m} / \mathrm{s}$, which produces maximum generation power, and iv) $25 \mathrm{~m} / \mathrm{s}$, the cut-out speed [21]. The cut-in-speed and cut-off speed of turbine were found to be $3-4 \mathrm{~m} / \mathrm{s}$ and $25 \mathrm{~m} / \mathrm{s}$ respectively in the research carried out [22].

Wind turbulence is an important site-characteristic, which impacts on power output and cause extreme loading on wind-turbine components. It refers to rapid disturbances or irregularities in wind speed and its direction and vertical component $[23,24]$. It is particularly crucial for small wind turbines, which in practice are typically installed near buildings, trees, and other obstacles. Wind turbulence level lower than $14 \%$ results into increased power output, while inconsistent trend is observed for higher turbulence-levels [25]. The turbulence level of 0.10 or below is low, 0.25 is moderate, and above 0.25 is high [18].

The wind power density (WPD) is the number of watts of electrical energy produced per square metre $\left(\mathrm{W} / \mathrm{m}^{2}\right)$ of air space. The WPD is categorized as fair $\left(\mathrm{P} / \mathrm{A}^{1}<100 \mathrm{~W} / \mathrm{m}^{2}\right)$, fairly good $\left(100 \mathrm{~W} / \mathrm{m}^{2} \leq \mathrm{P} / \mathrm{A}<300 \mathrm{~W} / \mathrm{m}^{2}\right)$, good $(300$ $\left.\mathrm{W} / \mathrm{m}^{2} \leq \mathrm{P} / \mathrm{A}<700 \mathrm{~W} / \mathrm{m}^{2}\right)$ and very $\operatorname{good}(\mathrm{P} / \mathrm{A} \geq 700$ $\mathrm{W} / \mathrm{m}^{2}$ ). Wind power density is characterized into seven groups whereas commercial wind power development becomes feasible around wind power class four (400-500 $\mathrm{W} / \mathrm{m}^{2}$ with $7-7.5 \mathrm{~m} / \mathrm{s}$ ) [26].

The usual method for estimation of power output from wind is using the turbine power curve and a wind speed frequency distribution. One of the frequency distributions is Weibull probability density. It is used to know wind condition at the selected site, to describe the distribution of wind speeds over time duration and to describe the probability density function of wind speed [27]. This distribution usually gives a very good fit to observed wind speed data [13], and it is widely accepted and most appropriated distribution function for wind data [11]. In general, this function has been applied by many researchers involved in wind speed analysis, and the corresponding Weibull model has also been widely adopted in wind power analysis.

\section{Methodology}

\subsection{Research sites}

${ }^{1} P$ is power available from the given air parcel and $A$ is cross-sectional area. 
The research sites are scattered in all the three ecological regions having varied altitudes and are located in the 13 districts of Nepal. These sites were selected either from the meteorological stations or from the installed dedicated met masts which had at least complete one-year hourly wind data with a maximum of $10 \%$ missing data. Four sites were located in the mountain region, eight sites in the hills and the remaining four sites lies in the Terai. Vorleni, Jumla, Patan west, Kagbeni and Thini are located in river corridor; Nepalgunj, Simara and Thalaha in flat low elevation; Okhaldhunga, Ramechhap, Nagarkot, Tansen, Baddanda and Hansapur are at the top of the hill; and Simikot and Fakhel are located in other category of topography in Mountain and hilly region respectively. The location of the sites is shown in figure 1.

The wind data at the 11 sites were measured at the height of $20 \mathrm{~m}$ or $30 \mathrm{~m}$ from the ground. In the case of the five metrological sites located at the airports, the wind data were measured at $10 \mathrm{~m}$ height. The latitude, longitude, data measurement period, elevation of the sites and the amount of the missing data are presented in table 1. All the sites except the two viz. Vorleni and Ramechhap had some missing data; Simikot had the maximum (10\%) missing data.

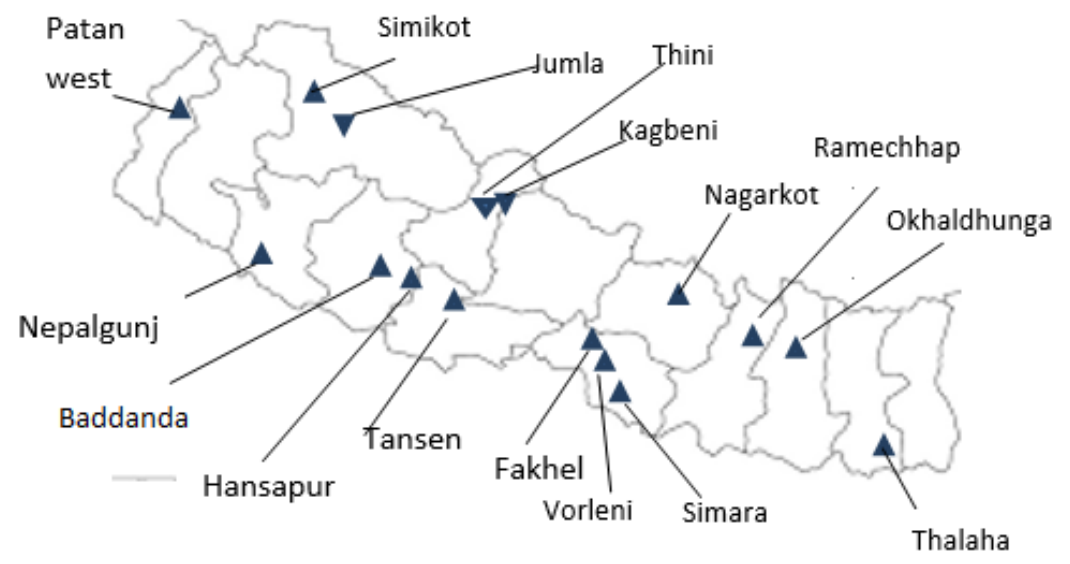

Figure 1: Location of the research sites

Table 1: Research sites

\begin{tabular}{|l|l|l|l|l|l|}
\hline Location & Longitude & Latitude & Measurement height (m) & Elevation of sites (m) & Missing data (\%) \\
\hline Simikot & 81.49 .11 & 29.58 .14 & 10 & 2,969 & 10.00 \\
\hline Jumla & 82.11 .35 & 29.16 .28 & 10 & 2,376 & 1.56 \\
\hline Patan west & 80.32 .57 & 29.27 .45 & 10 & 1,271 & 2.52 \\
\hline Simara & 84.59 .25 & 27.09 .43 & 10 & 135 & 2.45 \\
\hline Vorleni, & 85.24 .49 & 27.19 .08 & 20 & 240 & - \\
\hline Thalaha & 87.22 .47 & 26.30 .09 & 30 & 79 & 0.06 \\
\hline Fakhel & 85.13 .01 & 27.35 .57 & 20 & 1,829 & 0.03 \\
\hline Nagarkot & 85.31 .16 & 27.42 .52 & 20 & 1,907 & 6.62 \\
\hline Tansen & 83.33 .01 & 27.52 .05 & 20 & 1,305 & 0.25 \\
\hline Thini & 83.43 .34 & 28.46 .08 & 20 & 2,865 & 2.07 \\
\hline Kagbeni & 83.46 .55 & 28.50 .11 & 20 & 2,835 & 1.68 \\
\hline Okhaldhunga & 86.30 .12 & 27.18 .53 & 20 & 1,803 & 1.05 \\
\hline Ramechhap & 86.04 .55 & 27.19 .28 & 20 & 1,402 & - \\
\hline Hansapur & 82.54 .17 & 27.56 .01 & 20 & 853 & 4.41 \\
\hline Nepalgunj & 81.40 .07 & 28.06 .04 & 10 & 895 & 0.91 \\
\hline Baddanda & 82.49 .22 & 27.57 .27 & 20 & & 1.28 \\
\hline
\end{tabular}


Table 2: Shear coefficient

\begin{tabular}{|l|l|l|}
\hline Sample sites & Location category & Shear coefficient \\
\hline Simara, Tansen, Nepalgunj, Jumla, Simikot, Thini and Kagbeni & Small town with some trees and shrubs & $\alpha=0.30$ \\
\hline $\begin{array}{l}\text { Fakhel, Nagarkot, Hansapur, Baddanda, Ramechhap, } \\
\text { Okhaldhunga, Vorleni, Patan west and Thalaha }\end{array}$ & Wooded country with many trees & $\alpha=0.25$ \\
\hline
\end{tabular}

\subsection{Missing data}

The time series of the wind speed was cautiously examined to identify the missing data as well as the abnormally high and low wind speed of the study sites. The missing observed wind speed data are filled up by replacing the missing values with the annual average values of the wind speed using the following formula:

$$
M=\frac{\sum_{i=1}^{N} N_{i}}{N}
$$

Where, ' $M$ ' is missing data, ' $i$ ' is hourly annual wind speed at a specific location and ' $N$ ' is number of hours in a year.

\subsection{Vertical extrapolation of wind speed}

In order to make a reliable estimate of the wind turbine output, it is required to know the vertical profile of the wind speed [13]. From the atmospheric stability point of view, the vertical profile of the wind speed is variable in time, both on daily and seasonal basis. According to GB/T 18710-2002 standard ${ }^{2}$, the difference of $50 \mathrm{~m} / 30 \mathrm{~m}$ or $30 \mathrm{~m} / 10 \mathrm{~m}$ wind speed should be less than $2 \mathrm{~m} / \mathrm{s}$, and the difference of $50 \mathrm{~m} / 10 \mathrm{~m}$ wind speed should be less than 4 $\mathrm{m} / \mathrm{s}$ [28]. Three methods of vertical extrapolation commonly used in wind energy are i) power law profile modeling, ii) surface-based profile modeling, and iii) Computational Fluid Dynamics (CFD) wind flow modeling. Among these methods, the power law method is most used to adjust wind velocity at a reference-level to another above height.

The following form of the power law equation for vertical extrapolation to $50 \mathrm{~m}$ height from the ground was used in this study.

$$
V_{2}=V_{1}\left[\frac{z_{2}}{z_{1}}\right]^{\alpha}
$$

Where, $\mathrm{V}_{2}$ is wind speed at the required height $\mathrm{z}_{2} ; \mathrm{V}_{1}$ is wind speed at the reference height $z_{1}$; and $\alpha$ is wind shear/power law exponent.

The wind shear coefficient ' $\alpha$ ' is the change in horizontal wind speed with a change in height, and it depends on the surface roughness coefficient and lies in the range 0.05-
0.50 ; but in most of the cases, it is assumed to be 0.143 . Shear coefficient value over flat rigid ground is 0.10 whereas it is 0.15 for foot-high grass on level ground, 0.20 for tall crops, hedges, and shrubs, 0.25 for wooded country with many trees, 0.3 for small town with some trees and shrubs and 0.4 for city area with tall buildings $[29,30]$.

As the difference between the wind energy production using one seventh power law and the observed wind shear coefficient is up to $49.6 \%$, the wind shear exponent should be determined for each site, because its magnitude is influenced by site-specific characteristics [30]. In this research, the shear coefficient was determined on the basis of the sector-wise surface roughness and the equivalent roughness class [14] (see table 2).

\subsection{Wind data analysis}

Weibull power density function has been employed by many researchers [30] and has also been extensively used in wind power analysis for long period of time [31]. In this study too, the Weibull power density function was used for the purpose.

Wind power density (WPD) better represents the wind energy potential of a site than the wind speed alone. It is the wind power available per unit area swept by the turbine blades; the WPD in this study was calculated using the following formula:

$$
\mathrm{WPD}=\frac{1}{2 n} \sum_{i=1}^{n}(p) V_{i}^{3}
$$

Where ' $n$ ' is the total number of data points for each year i.e. 8760 ; ' $p$ ' is the air density $\left(\mathrm{kg} / \mathrm{m}^{3}\right)$; ' $\mathrm{v}_{\mathrm{i}}^{3}$ ' is the cube of the $\mathrm{i}^{\text {th }}$ wind speed value; and ' $\mathrm{i}$ ' is the measured hourly wind speed.

Similarly, wind power is directly proportional to the cube of the wind speed; following expression was used to calculate the wind power from the studied sites:

$$
P(v)=\frac{1}{2} \rho v^{3}
$$

Where $\rho$ is the standard air density at the sea level with an average temperature of $15^{\circ} \mathrm{c}$ and pressure of 1 atmosphere

${ }^{2}$ Chinese methodology of wind energy resource assessment for wind farm 
(atm) i.e. $1.225 \mathrm{~kg} / \mathrm{m}^{3}$, and $\mathrm{v}$ is the mean wind speed [31].

Several methods are practiced determining the Weibull shape and scale parameters [32]. The shape parameter was calculated with the help of the standard deviation and the average wind speed using the following formula:

$$
k=\left(\frac{\sigma}{v_{\text {avg }}}\right)^{-1.086}
$$

Where, $\mathrm{k}$ is the shape parameter; $\sigma$ is the standard deviation; and $\mathrm{v}_{\text {avg }}$ is the average wind speed.

The Weibull scale parameter ' $\mathrm{A}$ ' was calculated using the following equation:

$$
A=\frac{v_{\text {avg }} k^{2.6674}}{0.184+0.816 k^{2.73855}}
$$

The wind data is also analyzed according to time of the day and the season. The detailanalyses of the wind characteristics such as, average wind speed, availability and duration of wind, wind rose, wind power density and probability function were computed.

The Wind Atlas Analysis and Application Program (WAsP) model is commonly used for wind resource predictions [33] is applied in this study to analyze wind rose, power density including shape factor and Weibull probability function.

\section{$4 \quad$ Results and discussion}
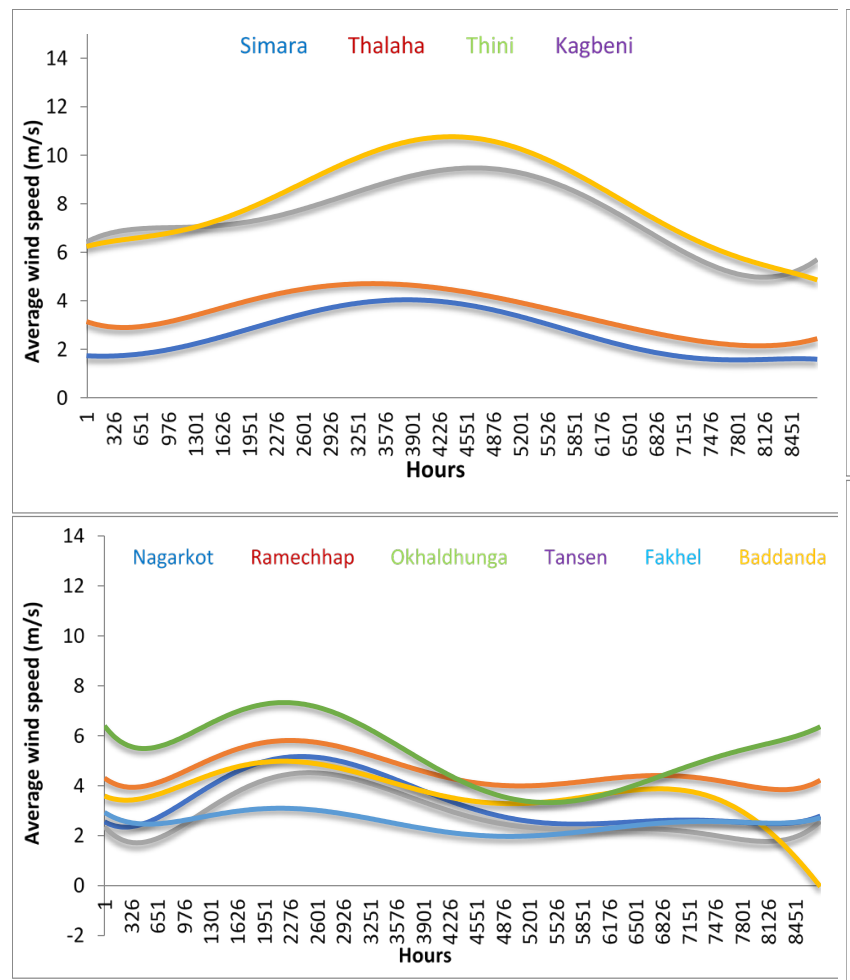

\subsection{Hourly, daily and seasonal variation of wind speed}

In order to assess the seasonal variation of the wind speed, the data were sorted hourly over a year, and plotted in the graph. Figure 2 indicate the time of the day and seasonal variations of the hourly average wind speed; the sites with similar time series wind speed variation are presented in one figure.

The time series of the average wind speed at the four sites viz. Simara, Thalaha, Thini and Kagbeni are shown in Figure 2. Kagbeni and Thini had the highest elevation ratio whereas Simara and Thalaha had the lowest one. Both Kagbeni and Thini are located at the river corridors in the mountain region whereas Simara and Thalaha are in the flat plain with the lowest elevation. The seasonal variation in the hourly wind speed of these four sites were found to be similar as presented in Figure 2a. In these sites, the wind speed was recorded to be in higher range from April to September; the value of the wind speed remained lowest in November, and gradually increased.

The average wind speed variations at the six sites viz. Okhaldhunga, Ramechhap, Nagarkot, Fakhel, Tansen and Baddanda are shown in figure 2. These sites were found to have highest wind speed during March, April and May, moderate wind speed during August, September, October and December. Similarly, the lowest wind speed was

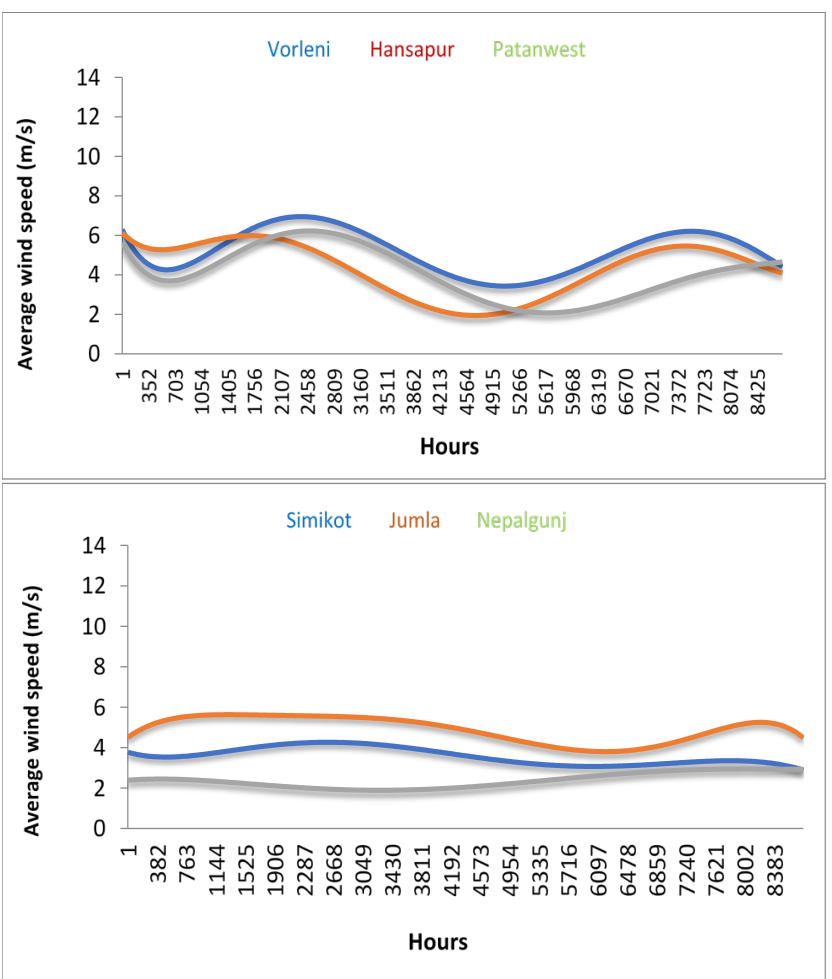

Figure 2: Hourly average wind speed 
recorded in the months of January, February, June, July and November.

The average wind speeds at Patan west, Hansapur and Vorleni were almost the same (figure 2); the wind speed values were observed to be in higher range during the months of March, April, May, September, October and November and were in lower range during January, February, June, July, August and December. As indicated in Figure 2, Simikot and Jumla were found to have the same wind speed trend whereas Nepalgunj had different trend of wind speed during the period of March-July. For the remaining months, these three sites had similar time series of wind speed.

All five research sites located at river corridor has above cut-in-speed average wind speed, although wind speed varied among sites. Three sites located in low elevation and flat land has low wind speed and the wind speed increases from west to east. Among six sites situated at the top of the hill, five have average wind speed above cut in speed and one below $3 \mathrm{~m} / \mathrm{s}$.

Nepal's electricity generation is dominated by hydropower. Winter and spring, from January to May, are dry season period and the river-discharge changes with the seasons in Nepal. During dry season, the energy production from the hydropower plants significantly decreases. As the wind speed in the studied sites remain to be in higher range during March to May, the wind power plants can compensate in reducing the decreasing energy production gap from the hydropower plants and contribute in fulfilling the shortage of electricity in the nation.

\subsection{Wind Rose}

The importance of wind rose is to design the wind turbine and setting the wind system. Wind rose is a tool which graphically displays wind speed and wind direction at a location over a period of time and presents in a circular format. As shown in figure 3 each concentric circle represents a different frequency, emanating from zero at the center to increasing frequencies at the outer circles. The length of each spoke around the circle is related to the frequency that the wind blows from a particular direction per unit time. Wind roses can be a yearly average or jcan be made for specific seasons; some even include air temperature information. The yearly average wind rose of the study sites are presented in Figure 3.

At all the sites, the wind was recorded to have blown in one or two major directions most of the time. The largest frequency of the wind at Thini, Kagbeni, Thalaha and
Ramechhap was concentrated in one direction. The wind was recorded to have blown from south-west at Thini, from south-east at Kagbeni, from north-west at Thalaha, and from south-west at Ramechhap. Around 50\% of the time, the wind was recorded to have blown from the same direction at Patan west, Vorleni, Fakhel, Nagarkot and Nepalgunj whereas it was recorded to have blown in two directions at Simikot, Simara, Hansapur, Jumla and Baddanda. Finally, the wind was recorded to have blown in relatively more dispersed directions at Tansen.

\subsection{Weibull probability distribution}

Detecting suitable wind speed distribution is commonly used in estimating wind energy potential of a specific location. Weibull probability distribution of the study sites are presented in Figure 4.The figure shows that the maximum frequency of the wind speed at the study sites is not similar and falls in different ranges: Thini (2 to $15 \mathrm{~m} / \mathrm{s})$, Kagbeni $(0.5$ to $15 \mathrm{~m} / \mathrm{s})$, Vorleni (2 to $10 \mathrm{~m} / \mathrm{s}$ ), Baddanda (1 to $11 \mathrm{~m} / \mathrm{s}$ ), Hansapur (1 to $10 \mathrm{~m} / \mathrm{s}$ ), Ramechhap ( 1 to $10 \mathrm{~m} / \mathrm{s})$, Jumla $(0.5$ to $10 \mathrm{~m} / \mathrm{s}$ ), Simikot ( 1 to $7 \mathrm{~m} / \mathrm{s}$ ), Patan west ( 1 to $7.5 \mathrm{~m} / \mathrm{s}$ ), Thalaha (1 to 7 $\mathrm{m} / \mathrm{s})$, Tansen $(0.5$ to $6.5 \mathrm{~m} / \mathrm{s})$, Nagarkot $(0.5$ to $6.5 \mathrm{~m} / \mathrm{s})$, Okhaldhunga ( 0.3 to $6 \mathrm{~m} / \mathrm{s})$, Simara $(0.5$ to $5 \mathrm{~m} / \mathrm{s})$, Fakhel $(0.5$ to $5 \mathrm{~m} / \mathrm{s}$ ) and Nepalgunj ( 0.5 to $5 \mathrm{~m} / \mathrm{s}$ ).

The shape factor $(\mathrm{k})$ represents the wind potential of the location and indicates how the wind distribution peaks. It describes the skewness of the distribution function. On the other hand, the scale factor (A) controls the average wind speed and is proportional to the average wind speed calculated from the entire distribution. The scale factor of the study sites varied from one location to another and remained between $2.6 \mathrm{~m} / \mathrm{s}$ (Nepalgunj) to $9.2 \mathrm{~m} / \mathrm{s}$ (Thini).

The shape factor of the study sites was found to be between 1.14 (Okhaldhunga) to 1.93 (Vorleni). As the skewness of the wind frequency distribution of all the sites is greater than ' +1 ', the distribution is highly skewed to the right (figure 4). Thus, the hourly distribution of the wind speed has less frequ ency to the right side of the average value, which means there is less time in the year for receiving higher wind speed. However, the distribution pattern differs from one location to another.

\section{Conclusion}

Eight sites viz. Jumla, Patan west, Vorleni, Thini, Kagbeni, Ramechhap, Hansapur and Baddanda) have the annual average wind speed of above the cut-in speed (3.5 $\mathrm{m} / \mathrm{s}$ ). These sites also have the wind speed above $3.5 \mathrm{~m} / \mathrm{s}$ for more than $50 \%$ time of a year. Wind power density is 


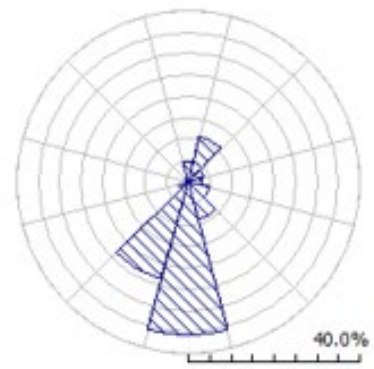

Thini

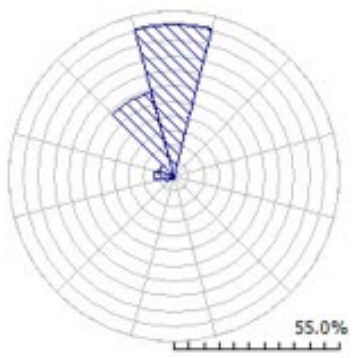

Thalaha

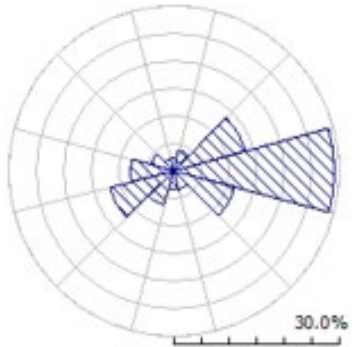

Patan West

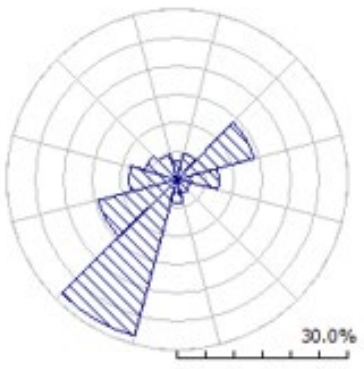

Fakhel

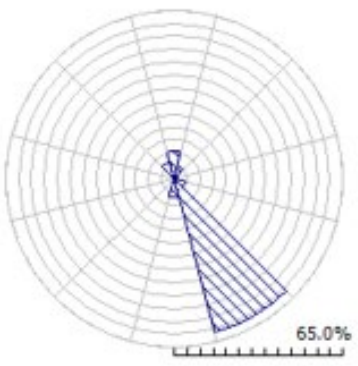

Kagbeni

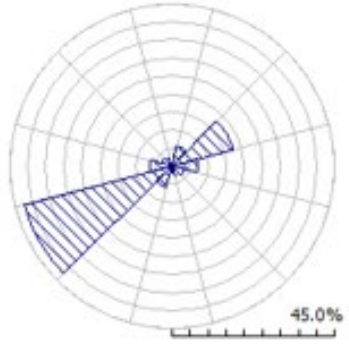

Ramechhap

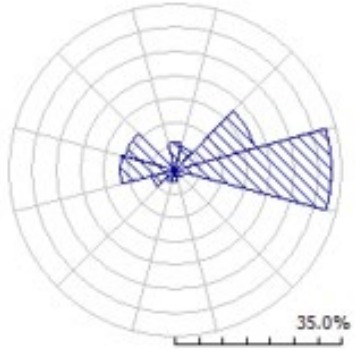

Vorleni

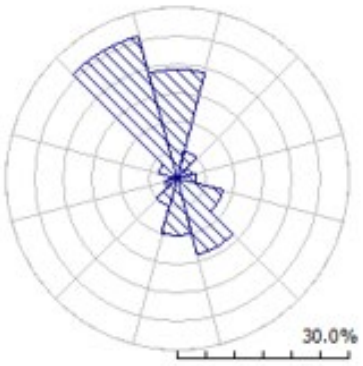

Nagarkot

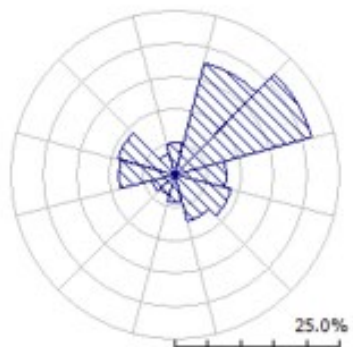

Nepalgunj

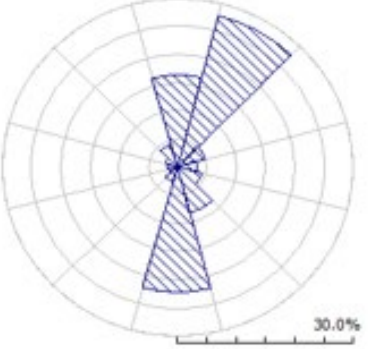

Simikot

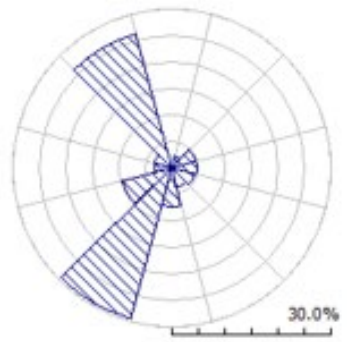

Baddanda

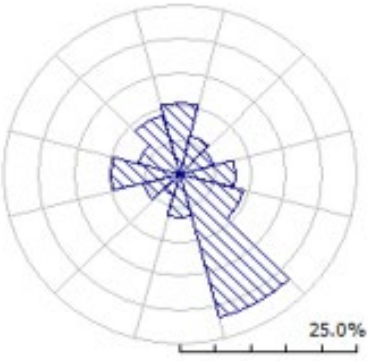

Tansen

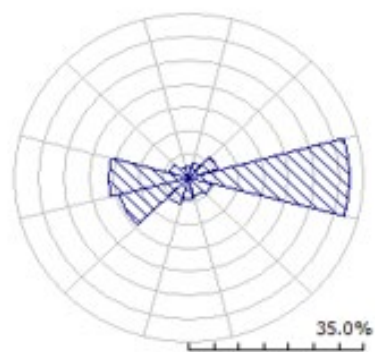

Okhaldhunga

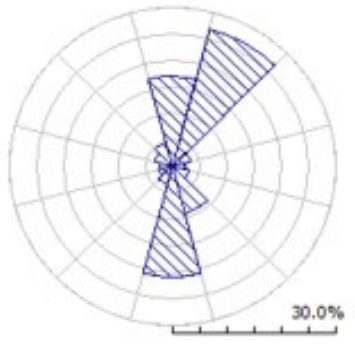

Simara

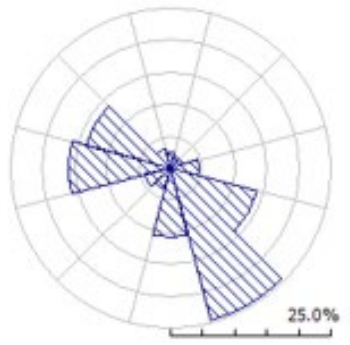

Jumla

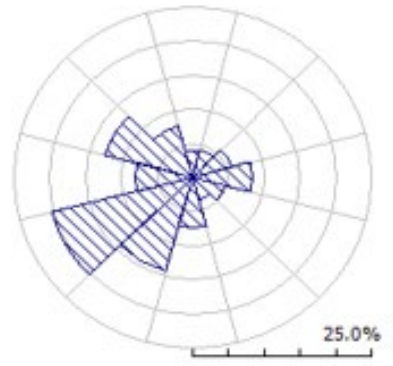

Hanspur

Figure 3: Wind Rose of the study sites

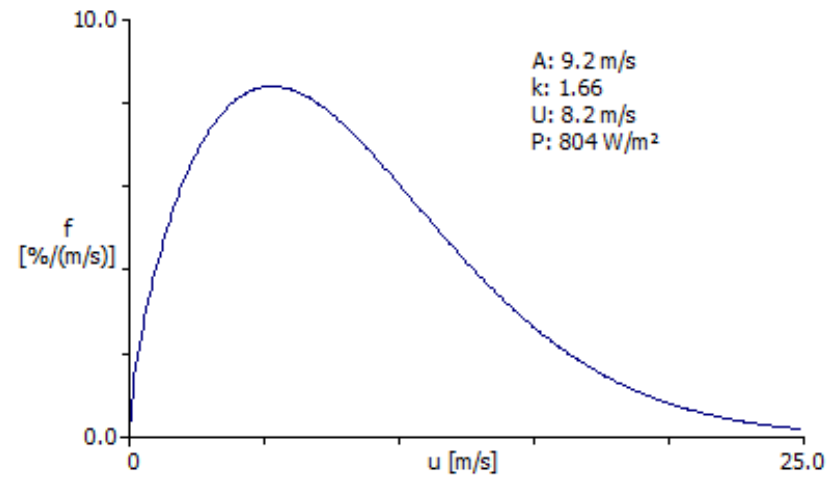

Thini

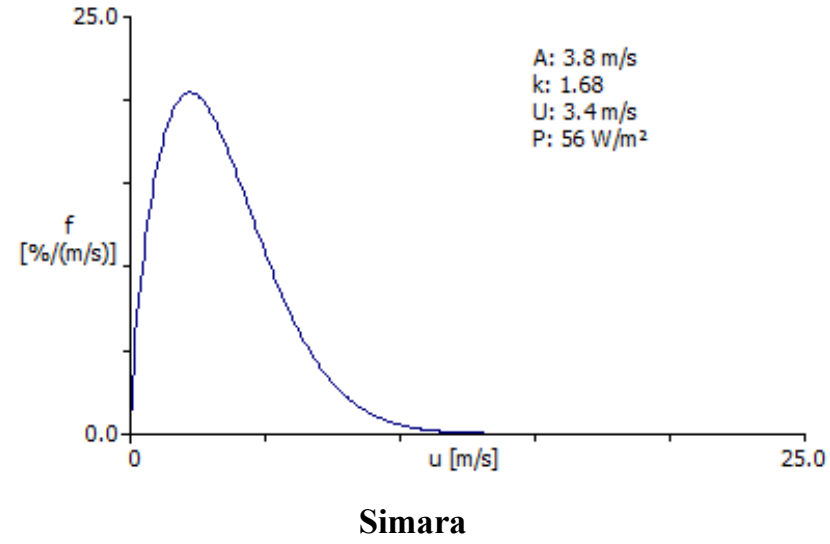


Wind Farming Feasibility Assessment in 16 Locations of Nepal
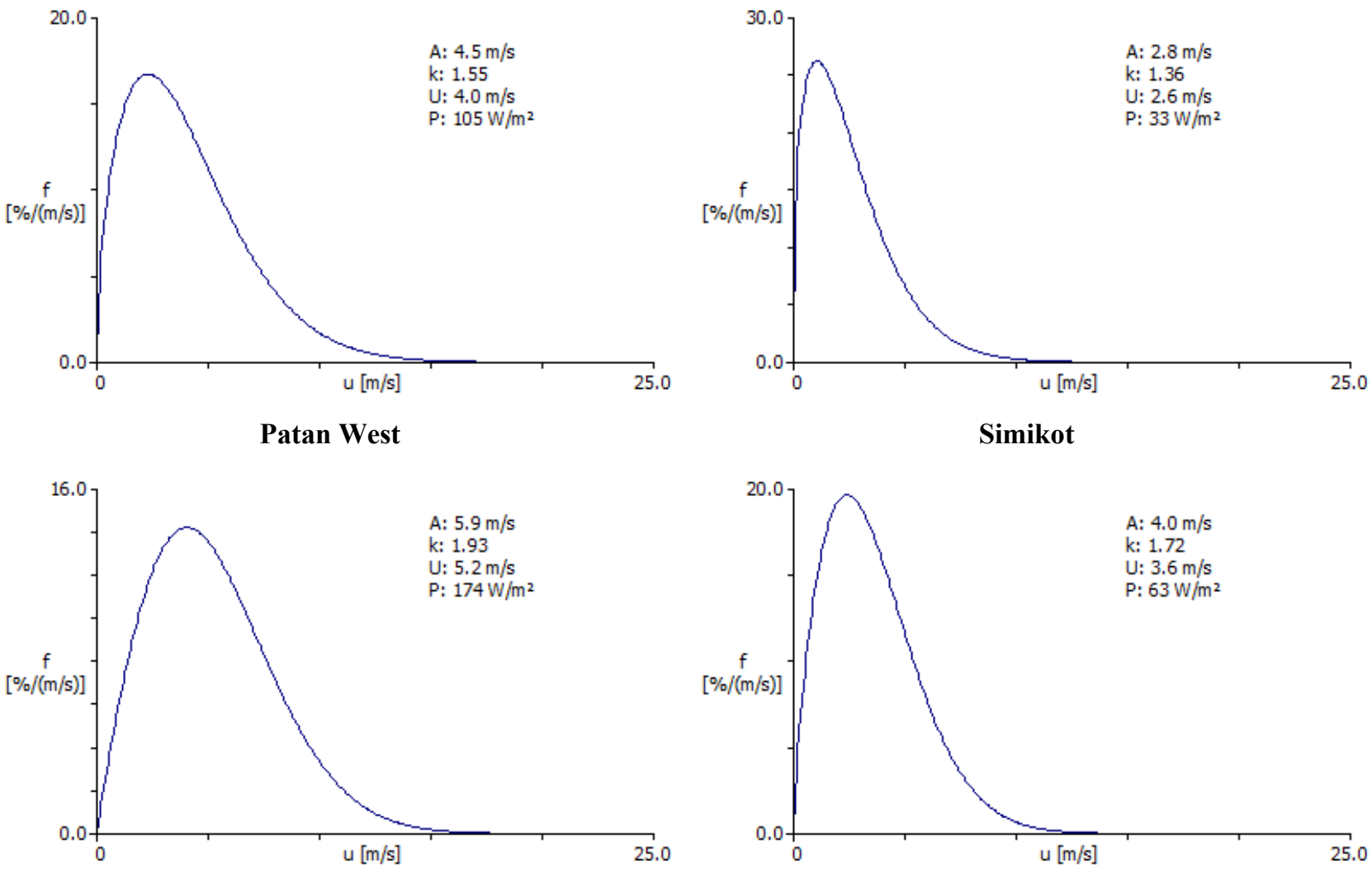

Vorleni

Thalaha
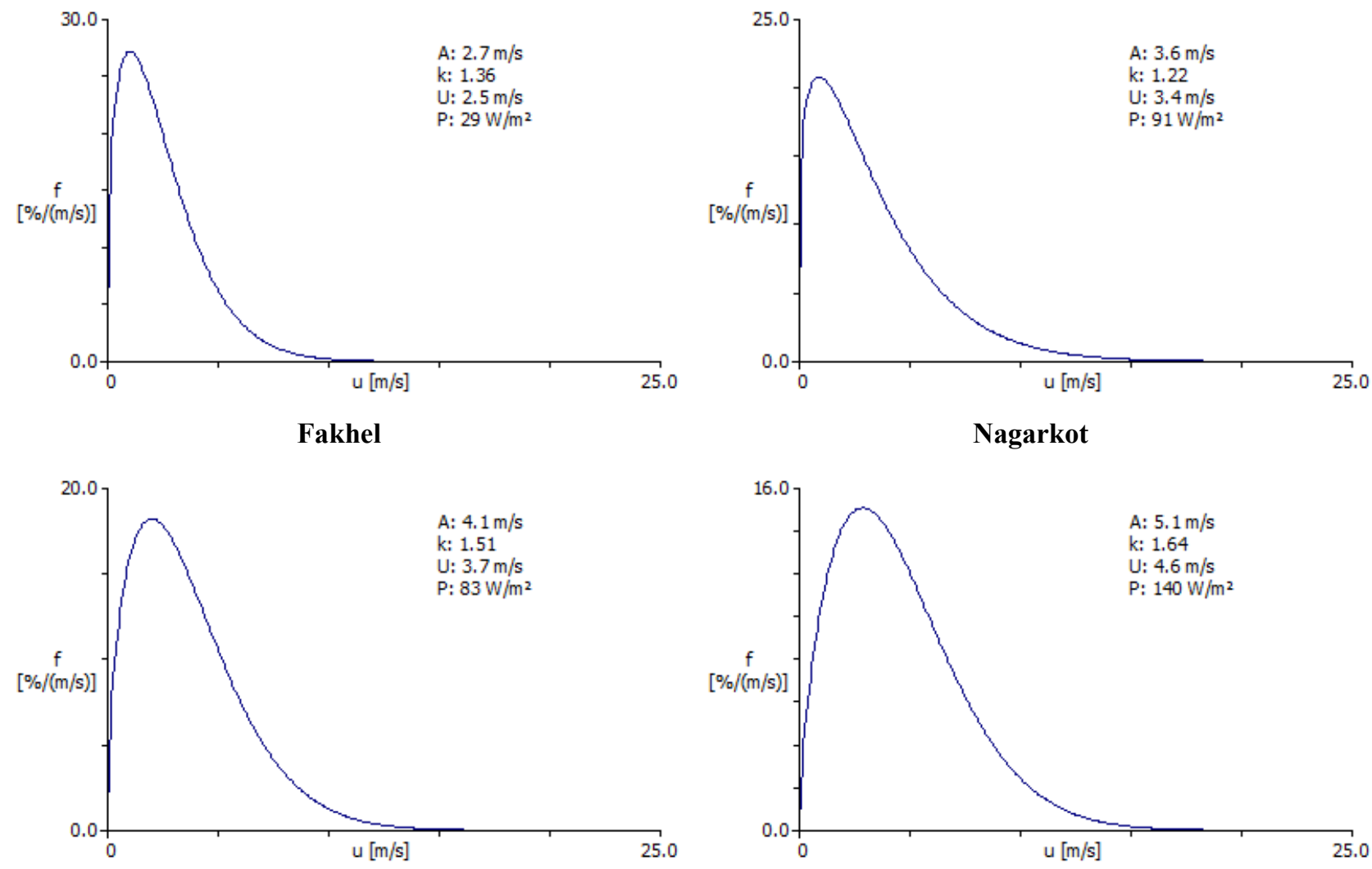

Tansen

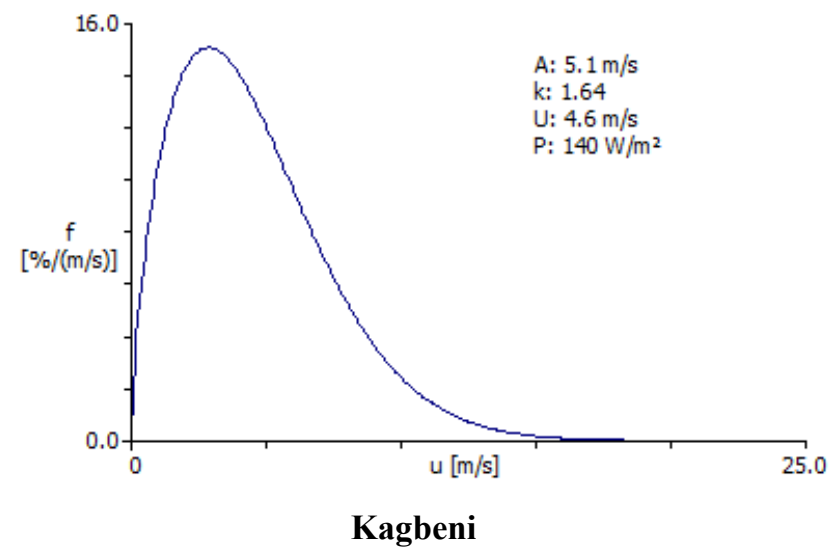



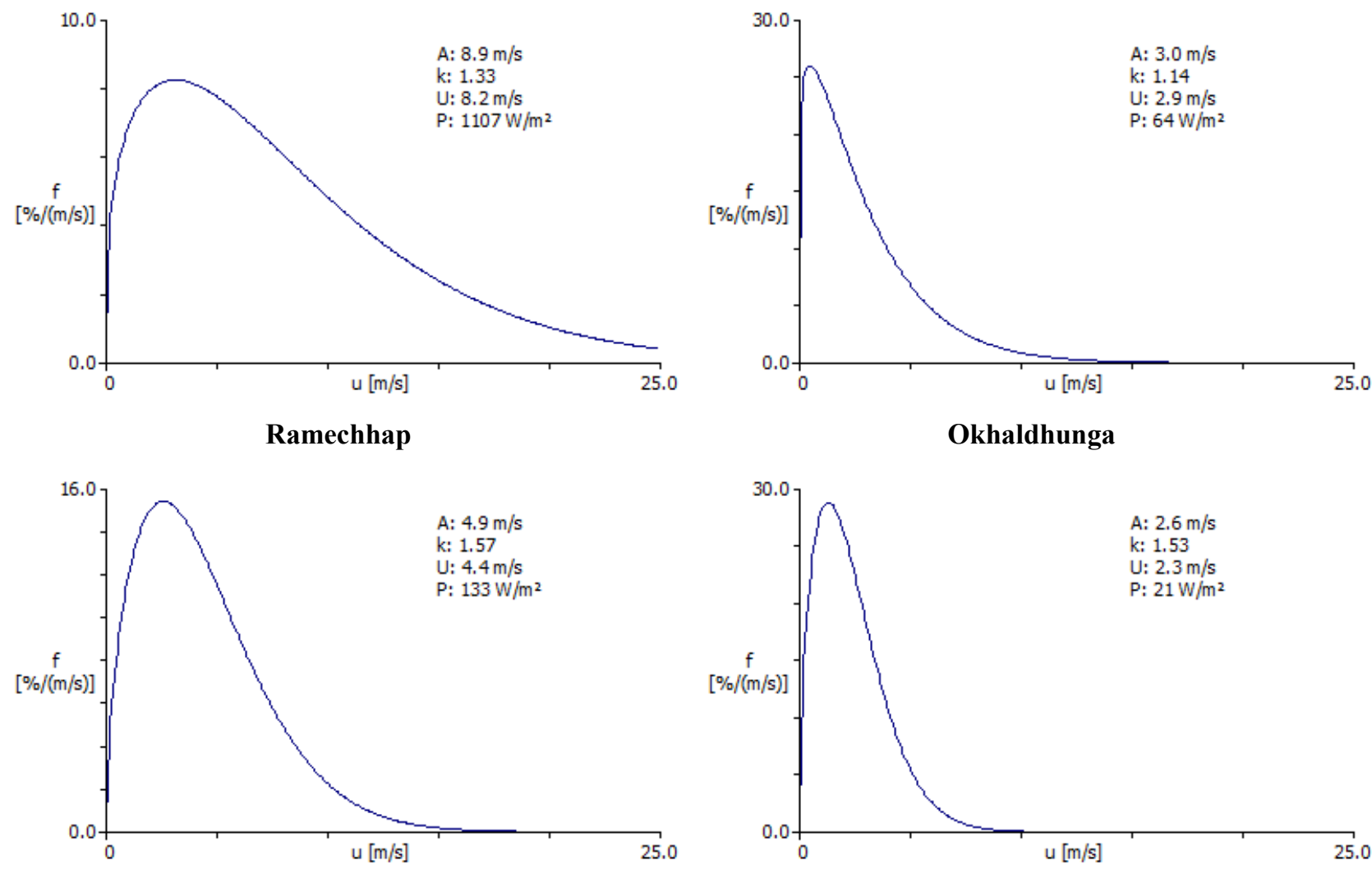

Hansapur

Nepalgunj
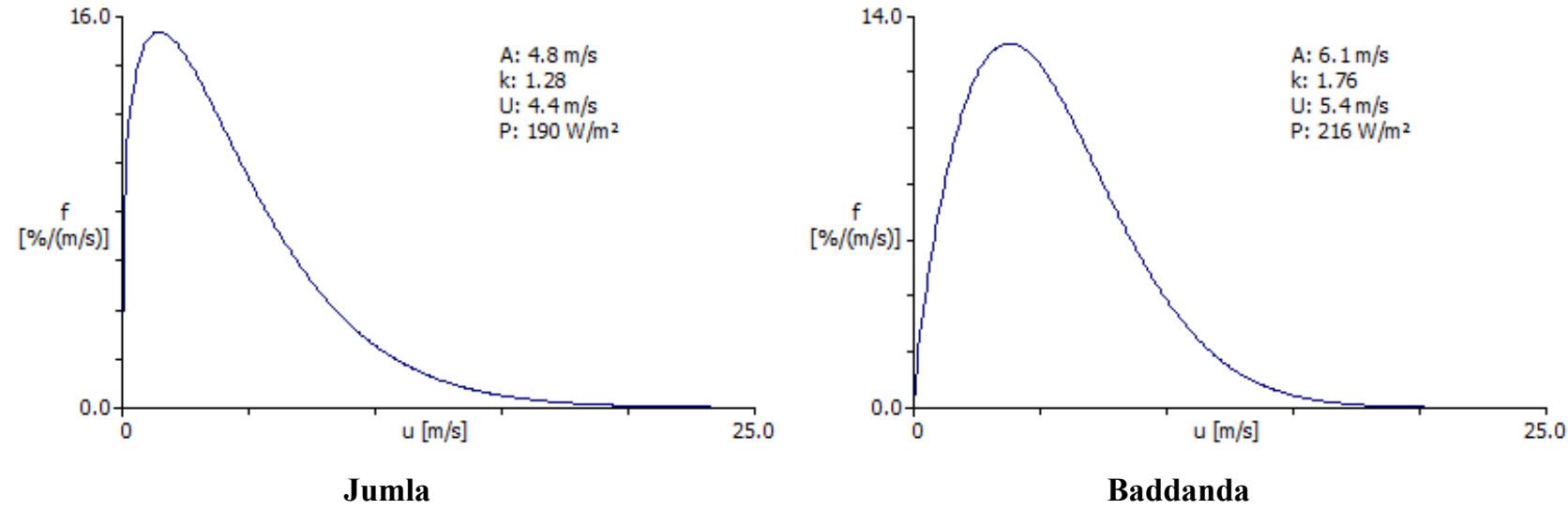

Figure 4: Weibull probability distribution of the study sites

proportional to the third moment of the wind speed distribution and to air density; therefore, a unique correspondence between wind power density and mean wind speed does not exist [34]. Out of the eight sites, the wind power density of the two sites falls in very good category and the six sites lies in fairly good. However, this is not sufficient condition. The turbulence intensity of these feasible sites was found to be in the range of 58-84 $\%$, which is quite higher than the acceptance intensity of $25 \%$. High turbulence negatively impacts upon energy production. The skewness of the wind frequency distribution of Vorleni was found to be the highest (1.93), and that of Jumla was found to be the lowest (1.28) among these eight study sites.

Out of the 16 research sites, two sites viz. Kagbeni and Thini are technically feasible for commercial-scale wind energy production while the six sites viz. Jumla, Patan west, Vorleni, Ramechhap, Hansapur and Baddanda are potential for small-scale wind energy generation. However, seasonal production of energy can be feasible in the four sites viz. Tansen, Thalaha, Simikot and Nagarkot as well considering the average wind speed and the WPD of the sites. Okhaldhunga, Fakhel, Nepalgunj and Simara are not suitable for wind power generation. 
As the higher wind speed is experienced during the dry season, the wind energy generation would be one of the appropriate options for supplying the electricity power when the power-yield from hydropower becomes the lowest. Furthermore, hybrid of wind power with solar energy can be appropriate option as the wind speed is higher during the nighttime and the solar energy is reach during the daytime, although detail cost benefit analysis needs to be carried before making the investment decision.

\section{Acknowledgement}

The authors are grateful to the Alternative Energy Promotion Centre, the Department of Hydrology and Meteorology, and the Nepal Academy of Science and Technology for providing the available observed hourly wind data of the study sites. This study would not have been possible without these data. The authors wish to thank Institute of Engineering, Tribhuvan University for providing the opportunity of accompanying this $\mathrm{PhD}$ research.

\section{References}

[1] Water and Energy Commission Secretariat, (2010), Energy Sector-Synopsis Report.

[2] Ministry of Finance, (2015), Economic Survey, Government of Nepal.

[3] Water and Energy Commission Secretariat, (2011), Water Resources of Nepal in the Context of Climate Change.

[4] Adhikari, K. R., Gurung, S., \& Bhattarai, B. K. (2013), Solar energy potential in Nepal and global context, Journal of the Institute of Engineering, 9(1), 95-106.

[5] Grieser, B., Sunak, Y., \& Madlener, R. (2015). Economics of small wind turbines in urban settings: An empirical investigation for Germany. Renewable Energy, 78, 334350 .

[6] International Energy Agency, (2014), How 2 Guide for Wind Energy: Roadmap Development and Implementation.

[7] Timilsina, G. R., van Kooten, G. C., \& Narbel, P. A., (2013), Global wind power development: Economics and policies, Energy Policy, 61, 642-652.

[8] United Nations Environment Programme/ Global Environment Facility \& Alternative Energy Promotion Centre (2006), Solar and Wind Energy Resource Assessment in Nepal (SWERA).

[9] United Nations Environment Programme/ Global Environment Facility \& Alternative Energy Promotion Centre (2008), Solar and Wind Energy Resource Assessment in Nepal (SWERA) - Final Report (GIS Part).
[10] Laudari, R., Sapkota, B., \& Banskota, K., (2018), Validation of wind resource in 14 locations of Nepal, Renewable energy, 119, 777-786.

[11] Khahro, S. F., Tabbassum, K., Soomro, A. M., Liao, X., Alvi, M. B., Dong, L., \& Manzoor, M. F., (2014), Technoeconomical evaluation of wind energy potential and analysis of power generation from wind at Gharo, Sindh Pakistan, Renewable and Sustainable Energy Reviews, 35, 460-474.

[12] Environmental Business, Renewable and non-Renewable Energy, Available online at http://www.environbusiness.com/eeae.

[13] Đurišić, Ž., \& Mikulović, J., (2012), A model for vertical wind speed data extrapolation for improving wind resource assessment using WAsP, Renewable Energy, 41, 407-411.

[14] Kim, H., \& Kim, B., (2016), Wind resource assessment and comparative economic analysis using AMOS data on a 30 MW wind farm at Yulchon district in Korea, Renewable Energy, 85, 96-103.

[15] Ritter, M., Shen, Z., Cabrera, B. L., Odening, M., \& Deckert, L., (2015), Designing an index for assessing wind energy potential, Renewable Energy, 83, 416-424.

[16] Troen, I., \& PETERSEN, E., (2016), European Wind Atlas. Roskilde: Risø National Laboratory, 1989.

[17] Shu, Z. R., Li, Q. S., \& Chan, P. W., (2015), Statistical analysis of wind characteristics and wind energy potential in Hong Kong, Energy Conversion and Management, 101, 644-657.

[18] AWS Scientific, Inc, \& National Renewable Energy Laboratory (US), (1997), Wind resource assessment handbook: Fundamentals for conducting a successful monitoring program, The Laboratory.

[19] Kawai, M., \& Pontines, V., (2014), Guidelines for wind resource assessment: Best practices for countries initiating wind development.

[20] Garrad, A., (1991), Vindenergi i Europa: en handlingsplan: en strategi til udnyttelse af det store vindkraftpotentiale i Europa: et sammendrag af Wind energy in Europe: time for action. European Wind Energy Assosiation.

[21] Level, Wind turbine systems, Available online at http://www.level.org.nz/energy/renewable-electricitygeneration/wind-turbine-systems.

[22] Belabes, B., Youcefi, A., Guerri, O., Djamai, M., \& Kaabeche, A., (2015), Evaluation of wind energy potential and estimation of cost using wind energy turbines for electricity generation in north of Algeria, Renewable and Sustainable Energy Reviews, 51, 1245-1255.

[23] McIntosh, S., Babinsky, H., \& Bertenyi, T., (2008, January), Unsteady power output of vertical axis wind 
turbines operating within a fluctuating free-stream, in 46th

AIAA Aerospace Sciences Meeting and Exhibit (p. 1324).

[24] F. Scheurich, Modelling the Aerodynamics of VerticalAxis Wnd Turbines, University of Glasgow, PhD Thesis, 2011.

[25] Pagnini, L. C., Burlando, M., \& Repetto, M. P., (2015), Experimental power curve of small-size wind turbines in turbulent urban environment, Applied Energy, 154, 112121.

[26] Ambrosini, G., Benato, B., Garavaso, C., Botta, G., Cenerini, M., Comand, D., \& Stork, C., (1992), Wind energy potential in Emilia Romagna, Italy, Journal of Wind Engineering and Industrial Aerodynamics, 39(1-3), 211-220.

[27] Karthikeya, B. R., Negi, P. S., \& Srikanth, N., (2016), Wind resource assessment for urban renewable energy application in Singapore, Renewable Energy, 87, 403-414.

[28] Yang, Z., Liu, Y., \& Li, C., (2011), Interpolation of missing wind data based on ANFIS, Renewable Energy, 36(3), 993-998.

[29] Patel M. R., (2006), Wind and solar power systems: design, analysis, and operation, CRC press.

[30] ur Rehman, S., Shoaib, M., Siddiqui, I., Ahmed, F., Tanveer, M. R., \& Jilani, S. U., (2015), Effect of wind shear coefficient for the vertical extrapolation of wind speed data and its impact on the viability of wind energy project, Journal of Basic and Applied Sciences, 11, 90100.

[31] Akdağ, S. A., Bagiorgas, H. S., \& Mihalakakou, G., (2010), Use of two-component Weibull mixtures in the analysis of wind speed in the Eastern Mediterranean, Applied Energy, 87(8), 2566-2573.

[32] Acker, T., \& Chime, A., (2011), Wind Modeling Using WindPro and WAsP Software; Sustainable Energy Solution Lab, Mechanical Engineering Department, Northern Arizona University: Flagstaff, AZ, USA, 1-11.

[33] Ouammi, A., Dagdougui, H., Sacile, R., \& Mimet, A., (2010), Monthly and seasonal assessment of wind energy characteristics at four monitored locations in Liguria region (Italy), Renewable and Sustainable Energy Reviews, 14(7), 1959-1968.

[34] Elliott, D. L., Holladay, C. G., Barchet, W. R., Foote, H. P., \& Sandusky, W. F., (1987), Wind energy resource atlas of the United States (No. DOE/CH/10093-4), Pacific Northwest Lab., Richland, WA (USA). 